\title{
Virulence characteristics of Escherichia coli isolates obtained from commercial one-week-old layer chicks with diarrhea
}

\author{
E. A. L. Guastalli ${ }^{2 *}$, B. H. L. Guastalli ${ }^{1}$, N. M Soares ${ }^{2}$, D.S.Leite ${ }^{3}$, A. A. lkuno ${ }^{4}$, R. P. Maluta ${ }^{1}$, M. \\ V. Cardozo ${ }^{1}$, L. G. Beraldo ${ }^{1}$, C. A. Borges ${ }^{1}$ and F. A. Ávila ${ }^{1}$ \\ ${ }^{1}$ Universidade Estadual Paulista Júlio de Mesquita Filho, Faculdade de Ciências Agrárias e Veterinárias de Jaboticabal, \\ Departamento de Patologia Veterinária, Brazil. \\ ${ }^{2}$ Instituto Biológico, Centro Avançando de Pesquisa Tecnológica do Agronegócio Avícola, Brazil. \\ ${ }^{3}$ Unicamp,Instituto de Biologia, Departamento de Genética, Evolução e Bioagentes, Brazil. \\ ${ }^{4}$ Instituto Biológico, Centro de Pesquisa e Desenvolvimento de Sanidade Animal, Brazil.
}

Accepted 26 July, 2013

\begin{abstract}
Ninety (90) strains of Escherichia coli were isolated from intestine with fecal contents and liver of seven days old commercial layers presenting diarrhea, and their pathogenicity was determined by in vivo inoculation into the air sacs of day-old chicks. The test revealed 44 strains with high and intermediate pathogenicity level that were analyzed by PCR for the presence of eight virulence genes, and their serogroups were indentified using a set of anti-O antisera. Results demonstrate that these isolated strains contained at least one of the eight genes searched and the majority of them $(93.20 \%)$ possessed gene iss. Seventeen (17) different genetic patterns have been detected with 15 having combinations of two or more genes representing $\mathbf{7 0 . 4 5 \%}$ of all analyzed strains. Eleven different serogroups were identified, and the highest frequent was 08 (15.89\%). Results demonstrate that strains that harbor genes iss or ast $A$ and some that belonged to serogroups 0133 and 0142 may have been crucial for the pathogenesis in the studied chicks, since several of these strains were pathogenic. The obtained results demonstrated the importance of studies in $E$. coli of avian origin in regions engaged in intensive poultry industry, aiming at evaluating the predominant strains and also acquiring preventive measures to minimize losses due to colibacillosis.
\end{abstract}

Key words: avian pathogenic Escherichia coli (APEC), layer chicks, polymerase chain reaction (PCR), virulence genes

\section{INTRODUCTION}

Strains of avian pathogenic Escherichia coli (APEC) are responsible for both systemic and localised infections in poultry. The disease known as colibacillosis results in significant morbidity and mortality, causing financial losses to the poultry industry which produces meat and eggs worldwide (Barnes et al., 2003). The bacterium affects birds of all ages, but the susceptibility to and severity of APEC are greatest in young birds (Montgomery et al., 1999; Johnson et al., 2001).
At a commercial layer farm, day-old chicks can arrive already infected with APEC (Guastalli et al., 2010). The infection can take place while the eggs are still in the incubator with transovarian transmission from infected hens to eggs or through egg shells contaminated by faeces. The bacterium penetrates through the egg shell, reach its interior and infects the embryo. Infected chicks that survive the first four days may develop serious infections and have compromised development. 
Table 1. Virulence genes, oligonucleotide sequences (primers), genomic locations, amplicon sizes, encoded virulence factors and primer references used in this study ${ }^{\mathrm{a}}$.

\begin{tabular}{|c|c|c|c|c|c|}
\hline Gene & Oligonucleotide sequence ( $5^{\prime}$ to $\left.3^{\prime}\right)$ & $\begin{array}{l}\text { Genomic } \\
\text { location }\end{array}$ & $\begin{array}{l}\text { Amplicon } \\
\text { size (bp) }\end{array}$ & $\begin{array}{l}\text { Encoded } \\
\text { virulence factor }\end{array}$ & $\begin{array}{l}\text { Reference } \\
\text { (primers) }\end{array}$ \\
\hline astA & $\begin{array}{l}\mathrm{F}=\text { TGC CAT CAA CAC AGT ATA TCC } \\
\mathrm{R}=\text { TCA GGT CGC GAG TGA CGG C }\end{array}$ & Chromosome & 116 & $\begin{array}{l}\text { Heat-stable } \\
\text { enteroaggregative } \\
\text { toxin }\end{array}$ & $\begin{array}{l}\text { Sanger et al. } \\
(1977)\end{array}$ \\
\hline irp2 & $\begin{array}{l}\mathrm{F}=\mathrm{AAG} \text { GAT TCG CTG TTA CCG GAC } \\
\mathrm{R}=\mathrm{AAC} \text { TCC TGA TAC AGG TGG C }\end{array}$ & Chromosome & 413 & $\begin{array}{l}\text { Protein of the iron- } \\
\text { acquisition system } \\
\text { by the bacterium }\end{array}$ & $\begin{array}{l}\text { Janßen et al. } \\
(2001)\end{array}$ \\
\hline papC & $\begin{array}{l}\mathrm{F}=\text { TGA TAT CAC GCA GTC AGT AGC } \\
\mathrm{R}=\mathrm{CCG} \text { GCC ATA TTC ACA TAA }\end{array}$ & Chromosome & 501 & P fimbria & $\begin{array}{l}\text { Franck et al. } \\
(1998)\end{array}$ \\
\hline vat & $\begin{array}{l}\mathrm{F}=T C C \text { TGG GAC ATA ATG GTC AG } \\
\mathrm{R}=\mathrm{GTG} \text { TCA GAA CGG AAT TGT }\end{array}$ & Chromosome & 981 & Vacuolating toxin & $\begin{array}{l}\text { Dozois et al. } \\
\text { (1992) }\end{array}$ \\
\hline$i u c \mathrm{D}$ & $\begin{array}{l}\mathrm{F}=A C A \text { AAA AGT TCT ATC GC TCC } \\
\mathrm{R}=\mathrm{CCT} \text { GAT CCA GAT GAT GCT C }\end{array}$ & Plasmid & 714 & Aerobactin & $\begin{array}{l}\text { Franck et al. } \\
(1998)\end{array}$ \\
\hline iss & $\begin{array}{l}\mathrm{F}=\mathrm{ATC} \text { ACA TAG GAT TCT GCC } \mathrm{G} \\
\mathrm{R}=\mathrm{CAG} \text { CGG AGT ATA GAT GCC A }\end{array}$ & Plasmid & 309 & $\begin{array}{l}\text { Protein for } \\
\text { increased serum } \\
\text { survival }\end{array}$ & $\begin{array}{l}\text { Dozois et al. } \\
\text { (1992) }\end{array}$ \\
\hline tsh & $\begin{array}{l}\mathrm{F}=\mathrm{ACT} \text { ATT CTC TGC AGG AAG TC } \\
\mathrm{R}=\mathrm{CTT} \text { CCG ATG TTC TGA ACG T }\end{array}$ & Plasmid & 824 & $\begin{array}{l}\text { Adhesin that is } \\
\text { sensitive to } \\
\text { temperature }\end{array}$ & $\begin{array}{l}\text { Dozois et al. } \\
\text { (1992) }\end{array}$ \\
\hline $\begin{array}{l}\text { cva A/B } \\
\text { cvi cvaC }\end{array}$ & $\begin{array}{l}\mathrm{F}=T G G \text { TAG AAT GTG CCA GAG CAA G } \\
\mathrm{R}=\mathrm{GAG} \text { CTG TTT GTA GCG AAG CC }\end{array}$ & Plasmid & 1181 & Colicin V & $\begin{array}{l}\text { Dozois et al. } \\
(1992)\end{array}$ \\
\hline
\end{tabular}

${ }^{a}$ Adapted from Ewers et al. (2005) and Kawano et al. (2006).

Furthermore, they may remain carriers and spreaders of pathogenic strains of E. coli (Barnes et al., 2003).

Several APEC serogroups were related to avian colibacillosis in Brazil and worldwide. According to Gross (1994), the most common serogroups are O1, O2, O8, O15, O18, O35, O78, O88, 0109 and 0115. However, many other serogroups that are rare, previously unknown and unable to be typed were detected (Menão et al., 2002; Silveira et al., 2002).

Through molecular biology, genes proposed as virulence factor markers in APEC have been determined (Ewers et al., 2005). Table 1 describes these genes, their genomic locations and their encoded virulence factors.

Considering these facts, the present work aims to investigate the presence of $E$. coli in seven-day-old chicks with diarrhea and apathy that are raised on commercial layer farms, to characterise the pathogenicity levels of the isolated strains through inoculation into the air sacs of day-old chicks and to identify the serogroups and virulence genes of these potentially pathogenic strains.

\section{MATERIALS AND METHODS}

This work is in accordance with the Ethical Principles in Animal Experimentation, adopted by the Brazilian College of Experimentation (COBEA) and was also approved by the Ethics and Animal Welfare (CEBEA), from São Paulo State University Animal Experimentation Ethics Committee, protocol n0. 026702-08.

\section{Origins of $E$. coli isolated}

Isolation of $E$. coli for the study was performed in 20 flocks of 7-dayold commercial layer chicks (producers of table eggs). Samplings were performed from August of 2008 to March of 2009 at different farms in the region of Bastos in São Paulo State, Brazil. Fifteen chicks from each flock with clinical signs of disease (smaller chicks in the flock with diarrhoea and apathy) were selected. These chicks were taken to the Unit of Research and Development of Bastos, where they were euthanised by cervical dislocation (approved by the São Paulo State University Animal Experimentation Ethics Committee - CEBEA, protocol n. 026702-08). One pool of liver fragments (15 animals) and another of intestines (in separated vessels) were collected aseptically from each flock.

\section{E. coli isolation and identification}

To isolate $E$. coli, a pre-culture of organ fragments was developed in Brain Heart Infusion $(\mathrm{BHI})$ at $37^{\circ} \mathrm{C}$ for $18 \mathrm{~h}$. Thereafter, the cultures were plated onto Eosin Methylene Blue agar (EMB) at $37^{\circ} \mathrm{C}$ for $24 \mathrm{~h}$. Between three and six colonies of each organ pool, lactose fermenters (metallic green) were isolated and inoculated into separate tubes containing triple sugar iron agar (TSI) and incubated at $37^{\circ} \mathrm{C}$ for $24 \mathrm{~h}$. The colonies inoculated into TSI that showed typical $E$. coli behaviours, such as glucose and lactose fermentation with gas production and the absence of $\mathrm{H}_{2} \mathrm{~S}$, were confirmed by a biochemical series based on citrate utilisation, indol 
production, methyl red and Voges-Proskauer reactions (Koneman et al., 1997). The isolated E. coli strains were stored on Luria Bertani agar.

\section{Pathogenicity test in day-old chicks}

Ten day-old male chicks obtained from a commercial source were used to determine the pathogenicity of each isolate. For this purpose, E. coli isolates were cultivated in $\mathrm{BHI}$ broth $(10 \mathrm{~mL})$ for 18 $\mathrm{h}$ at $37^{\circ} \mathrm{C}$. Chicks were challenged with $0.1 \mathrm{~mL}$ of the culture containing approximately $10^{7}$ colony-forming units $/ \mathrm{mL}(\mathrm{CFU} / \mathrm{mL})$ by inoculation into the left thoracic air sac of each chick (Dho-Moulin and Lafont, 1982; Monroy et al., 2005).

Chicks inoculated with culture medium $(\mathrm{BHI})$ alone and with $E$. coli K12 strain that belong to the culture collection of the Laboratory of Bacterial Antigens II of the Department of Microbiology and Immunology of the Institute of Biology of the University of Campinas (Campinas/SP-Brazil) at the same concentration, served as negative controls. A standard E. coli strain (EC55 - serogroup O1 that belongs to the culture collection of the Laboratory of Avian Disease of the University of São Paulo - USP (São Paulo/SP Brazil) was used as a positive control of pathogenicity (Guastalli et al., 2010).

The chicks were observed daily for ten days, and the strains were classified according to the following mortality index: highly pathogenic (mortality $\geq 80 \%$ ), intermediate pathogenicity (mortality $>50 \%$ but $<80 \%$ ), low pathogenicity (mortality $\leq 50 \%$ ) and nonpathogenic (no mortality) (Monroy et al., 2005).

\section{Multiplex polymerase chain reaction (PCR)}

The strains were analysed for the presence of the genes astA, iss, irp2, papC, iucD, tsh, vat and cvi-cva, whose primers, amplicons and gene locations are shown in Table 1. The strains EC 29 (cvacvit, vat+, tsh+, iucD+, Irp2+, iss+) and M64 (astA+, iss+, irp2+, papC+, iucD+, tsh+ and cvi/cva+) were used as positive controls (Ikuno et al., 2006). These strains were isolated from layer hens and belong to the bacterial collection of the Laboratory of Immunology of the Instituto Biológico (São Paulo/SP, Brazil).

DNA template preparation was performed using the Wizard Genomic DNA Purification Kit (Cat.\# A1120, Promega Corporation, Madison, WI) according to the manufacturer's instructions. Multiplex PCR reactions were performed according to Ewers et al. (2005) with slight modifications: a total of $2 \mu \mathrm{L}$ of each DNA template were added to a mix containing $1.25-2.50 \mu \mathrm{L}$ of each primer $(0.5-1$ $\mu \mathrm{M}), 1 \mu \mathrm{L}$ of each dNTP (100 $\mu \mathrm{M}$ each); $2.5 \mu \mathrm{L}$ of PCR buffer (10x), $4 \mu \mathrm{L}$ of $25 \mathrm{mM} \mathrm{MgCl}_{2}$ and $2.5 \mathrm{U}$ of Taq DNA polymerase (Fermentas, Europe), with a final volume of $25 \mu \mathrm{L}$. Amplification was carried out using a GeneAmp 2400 PCR System Thermal Cycler (Perkin Elmer, Waltham, MA) with the following conditions: $\mathrm{t} 1,3 \mathrm{~min}$ at $94^{\circ} \mathrm{C} ; \mathrm{t} 2,30 \mathrm{~s}$ at $94^{\circ} \mathrm{C} ; \mathrm{t} 3,30 \mathrm{~s}$ at $58^{\circ} \mathrm{C} ; \mathrm{t} 4,3 \mathrm{~min}$ at $68^{\circ} \mathrm{C}$ (t2-t4, 30 repeated cycles) and $t 5,10 \mathrm{~min}$ at $72^{\circ} \mathrm{C}$. Analysis of the amplified products was performed by electrophoresis ( $50 \mathrm{~V}$ for $2.5 \mathrm{~h}$ ) with a $1.5 \%$ agarose gel stained with ethidium bromide in TAE buffer (40 mM Tris-acetate, $1 \mathrm{mM}$ EDTA, $\mathrm{pH}$ 8.0) and using 100-bp DNA ladder (Fermentas, Europe). Gel images were recorded using an Alpha Imager Photodocumenter 1220 (Alpha Innotech Corp., San Leandro, CA) connected to a computer.

\section{Serogroup determinations}

Serogroup determinations were performed according to the microplate technique (Guinée et al., 1972; Blanco et al., 1992) using an anti-O antisera collection (O1 to $\mathrm{O} 185$ ) belonging to the Laboratory of Bacterial Antigens II of the Department of
Microbiology and Immunology of the Institute of Biology of the University of Campinas (Campinas/SP-Brazil).

\section{RESULTS}

Out of 20 studied flocks, 19 tested positive for E. coli, and 90 strains were isolated. As illustrated in Table 2, the number of strains from each flock varied from one to six, pathogenicity test in 1-day-old chicks revealed that 23 (25.55\%), 21 (23.33\%), 23 (25.55\%) and 23 (25.55\%) isolated were of highly, intermediate, low pathogenicity and non-pathogenic, respectively. During this test, all chicks of the positive control group died, while all chicks of the negatives controls group remained alive until the end of the experiment.

Macroscopic lesions were observed on necropsy on the chicks that died after the fourth day of inoculation. The lesions with the highest frequencies were airsacculitis (involving both air sacs) and yolk sac infections. Occasionally, pericarditis, perihepatitis, peritonitis with fibrin deposits and enteritis were found. Clinical signs, including diarrhoea and compromised body development, were also observed in some chicks. Clinical signs and macroscopic lesions occurred more frequently among chicks inoculated with strains classified with high and intermediate pathogenicity levels.

The 44 strains with high and intermediate pathogenicity levels had their serogroups and virulence genes determined. Serogroup characterisation revealed 26 serogrouped strains, in which 11 different serogroups were identified: O8 (15.89\%), O9 (2.27\%), O15 (4.54\%), O23 (9.08\%), O64 (4.54\%), O75 (4.54\%), O83 (6.81\%), $\mathrm{O} 112(2.27 \%), \mathrm{O} 133$ (4.54\%), O140 (2.27\%) and 0142 $(2.27 \%)$. For 18 strains $(40.90 \%)$, serogroups could not be determined.

All potentially pathogenic strains in the pathogenicity test in day-old chicks contained at least one of the eight studied genes. Table 3 presents the results according to the number of strains and percent occurrence of each virulence gene.

No strain possessed all eight studied virulence genes, but $31(70.45 \%)$ possessed more than one virulence gene. Seventeen genetic patterns were identified, of which two possessed only one gene and fifteen possessed an association of two or more genes. More strains were noticed at genetic patterns $\mathrm{P} 13$ and $\mathrm{P} 15$. Table 4 presents the genetic patterns of the E. coli strains with high and intermediate pathogenicity levels, associated with the serogroups and organs in which they were isolated.

\section{DISCUSSION}

The pathogenicity of an E. coli strain is based on the presence and expression of potential virulence factors (Won et al., 2009). According to Mellata et al. (2003), a 
Table 2. Results of pathogenicity tests in day-old chicks of strains isolated from seven days old commercial layers presenting diarrhea.

\begin{tabular}{|c|c|c|c|c|c|}
\hline \multirow{2}{*}{$\begin{array}{l}\text { Flock of } \\
\text { chicks }\end{array}$} & \multirow{2}{*}{$\begin{array}{c}\text { Number of } E \text {. coli } \\
\text { isolates }\end{array}$} & \multirow{2}{*}{$\begin{array}{l}\text { Organ from } E . \text { coli } \\
\text { isolates }\end{array}$} & \multicolumn{2}{|c|}{ Mortality index } & \multirow{2}{*}{$\begin{array}{l}\text { Pathogenicity } \\
\text { classification }\end{array}$} \\
\hline & & & $\begin{array}{l}\text { Number of birds } \\
\text { dead/challenged }\end{array}$ & $\begin{array}{c}\text { Mortality } \\
(\%)\end{array}$ & \\
\hline \multirow{3}{*}{ A } & 1 & Liver & $8 / 10$ & 80 & High \\
\hline & 2 & Liver & $8 / 10$ & 80 & High \\
\hline & 3 & Intestine & $9 / 10$ & 90 & High \\
\hline \multirow{3}{*}{ B } & 4 & Liver & $5 / 10$ & 50 & Intermediate \\
\hline & 5 & Liver & $7 / 10$ & 70 & Intermediate \\
\hline & 6 & Intestine & $8 / 10$ & 80 & High \\
\hline \multirow{6}{*}{ C } & 7 & Liver & $4 / 10$ & 40 & Low \\
\hline & 8 & Liver & $8 / 10$ & 80 & High \\
\hline & 9 & Liver & $4 / 10$ & 40 & Low \\
\hline & 10 & Intestine & $7 / 10$ & 70 & Intermediate \\
\hline & 11 & Intestine & $5 / 10$ & 50 & Intermediate \\
\hline & 12 & Intestine & $6 / 10$ & 60 & Intermediate \\
\hline \multirow{6}{*}{$\mathrm{D}$} & 13 & Liver & $9 / 10$ & 90 & High \\
\hline & 14 & Liver & $7 / 10$ & 70 & Intermediate \\
\hline & 15 & Liver & $2 / 10$ & 20 & Low \\
\hline & 16 & Intestine & $10 / 10$ & 100 & High \\
\hline & 17 & Intestine & $0 / 10$ & 0 & Non-pathogenic \\
\hline & 18 & Intestine & $10 / 10$ & 100 & High \\
\hline \multirow{4}{*}{$E$} & 19 & Liver & $1 / 10$ & 10 & Low \\
\hline & 20 & Intestine & $3 / 10$ & 30 & Low \\
\hline & 21 & Intestine & $8 / 10$ & 80 & High \\
\hline & 22 & Intestine & $1 / 10$ & 10 & Low \\
\hline \multirow{2}{*}{$\mathrm{F}$} & 23 & Intestine & $10 / 10$ & 100 & High \\
\hline & 24 & Intestine & $9 / 10$ & 90 & High \\
\hline$G$ & 25 & Intestine & $0 / 10$ & 0 & Non-pathogenic \\
\hline \multirow{6}{*}{$\mathrm{H}$} & 26 & Liver & $0 / 10$ & 0 & Non-pathogenic \\
\hline & 27 & Liver & $0 / 10$ & 0 & Non-pathogenic \\
\hline & 28 & Liver & $1 / 10$ & 10 & Low \\
\hline & 29 & Intestine & $0 / 10$ & 0 & Non-pathogenic \\
\hline & 30 & Intestine & $0 / 10$ & 0 & Non-pathogenic \\
\hline & 31 & Intestine & $10 / 10$ & 100 & High \\
\hline \multirow{6}{*}{ I } & 32 & Liver & $3 / 10$ & 30 & Low \\
\hline & 33 & Liver & $6 / 10$ & 60 & Intermediate \\
\hline & 34 & Liver & $0 / 10$ & 0 & Non-pathogenic \\
\hline & 35 & Intestine & $0 / 10$ & 0 & Non-pathogenic \\
\hline & 36 & Intestine & $0 / 10$ & 0 & Non-pathogenic \\
\hline & 37 & Intestine & $2 / 10$ & 20 & Low \\
\hline \multirow{6}{*}{$J$} & 38 & Liver & $7 / 10$ & 70 & Intermediate \\
\hline & 39 & Liver & $1 / 10$ & 10 & Low \\
\hline & 40 & Liver & $6 / 10$ & 60 & Intermediate \\
\hline & 41 & Intestine & $0 / 10$ & 0 & Non-pathogenic \\
\hline & 42 & Intestine & $9 / 10$ & 90 & High \\
\hline & 43 & Intestine & 0 & 0 & Non-pathogenic \\
\hline
\end{tabular}


Table 2. Contd.

\begin{tabular}{|c|c|c|c|c|c|}
\hline \multirow{4}{*}{ K } & 44 & Liver & $8 / 10$ & 80 & High \\
\hline & 45 & Liver & $8 / 10$ & 80 & High \\
\hline & 46 & Intestine & $10 / 10$ & 100 & High \\
\hline & 47 & Intestine & $5 / 100$ & 50 & Intermediate \\
\hline \multirow{4}{*}{ M } & 48 & Liver & $3 / 10$ & 30 & Low \\
\hline & 49 & Liver & $0 / 10$ & 0 & Non-pathogenic \\
\hline & 50 & Intestine & $2 / 10$ & 20 & Low \\
\hline & 51 & Intestine & $6 / 10$ & 60 & Intermediate \\
\hline \multirow{5}{*}{$N$} & 52 & Liver & $0 / 10$ & 10 & Low \\
\hline & 53 & Liver & $0 / 10$ & 0 & Non-pathogenic \\
\hline & 54 & Liver & $1 / 10$ & 10 & Low \\
\hline & 55 & Intestine & $0 / 10$ & 0 & Non-pathogenic \\
\hline & 56 & Intestine & $0 / 10$ & 0 & Non-pathogenic \\
\hline \multirow{5}{*}{$\mathrm{O}$} & 57 & Liver & $0 / 10$ & 0 & Non-pathogenic \\
\hline & 58 & Liver & $0 / 10$ & 0 & Non-pathogenic \\
\hline & 59 & Intestine & $0 / 10$ & 0 & Non-pathogenic \\
\hline & 60 & Intestine & $8 / 10$ & 80 & High \\
\hline & 61 & Intestine & $0 / 10$ & 0 & Non-pathogenic \\
\hline \multirow{6}{*}{$P$} & 62 & Liver & $1 / 10$ & 10 & Low \\
\hline & 63 & Liver & $6 / 10$ & 60 & Intermediate \\
\hline & 64 & Liver & $7 / 10$ & 70 & Intermediate \\
\hline & 65 & Intestine & $4 / 10$ & 40 & Low \\
\hline & 66 & Intestine & $6 / 10$ & 60 & Intermediate \\
\hline & 67 & Intestine & $5 / 10$ & 50 & Intermediate \\
\hline \multirow{6}{*}{ Q } & 68 & Liver & 0 & 0 & Non-pathogenic \\
\hline & 69 & Liver & 0 & 0 & Non-pathogenic \\
\hline & 70 & Liver & 0 & 0 & Non-pathogenic \\
\hline & 71 & Intestino & $4 / 10$ & 40 & Low \\
\hline & 72 & Intestino & $10 / 10$ & 100 & High \\
\hline & 73 & Intestino & $0 / 10$ & 0 & Non-pathogenic \\
\hline \multirow{6}{*}{$\mathrm{R}$} & 74 & Liver & $0 / 10$ & 0 & Non-pathogenic \\
\hline & 75 & Liver & $6 / 10$ & 60 & Intermediate \\
\hline & 76 & Liver & $10 / 10$ & 100 & High \\
\hline & 77 & Intestine & $6 / 10$ & 60 & Intermediate \\
\hline & 78 & Intestine & $6 / 10$ & 60 & Intermediate \\
\hline & 79 & Intestine & $5 / 10$ & 50 & Intermediate \\
\hline \multirow{6}{*}{ S } & 80 & Liver & $4 / 10$ & 40 & Intermediate \\
\hline & 81 & Liver & $2 / 10$ & 20 & Low \\
\hline & 82 & Liver & $10 / 10$ & 100 & High \\
\hline & 83 & Liver & $1 / 10$ & 10 & Low \\
\hline & 84 & Intestine & $10 / 10$ & 100 & High \\
\hline & 85 & Intestine & $10 / 10$ & 100 & High \\
\hline
\end{tabular}


Table 2. Contd.

\begin{tabular}{|c|c|c|c|c|c|}
\hline & 86 & Liver & $2 / 10$ & 20 & Low \\
\hline & 87 & Liver & $7 / 10$ & 70 & Intermediate \\
\hline \multirow[t]{5}{*}{$\mathrm{T}$} & 88 & Liver & $2 / 10$ & 20 & Low \\
\hline & 89 & Liver & $5 / 10$ & 50 & Intermediate \\
\hline & 90 & Intestine & $8 / 10$ & 80 & High \\
\hline & ${ }^{\mathrm{a}}$ E. coli 55 & & $10 / 10$ & 100 & High \\
\hline & ${ }^{\mathrm{b}}$ E.coli K12 & & 0 & 0 & Non-pathogenic \\
\hline
\end{tabular}

${ }^{\mathrm{a}} E$. coli $\mathrm{EC} 55$ strain was used as a positive control; ${ }^{\mathrm{b}} E$. coli $\mathrm{K} 12$ strain was used as a negative control.

Table 3. Number of strains and percent occurrence of virulence genes in the analysed E.coli strains.

\begin{tabular}{lcccccccc}
\hline Gene & iss & astA & iucD & irp2 & cvi/cva & vat & tsh & papC \\
\hline No. of strains & 41 & 18 & 19 & 12 & 8 & 4 & 6 & 3 \\
$\%$ & 93.2 & 40.1 & 43.2 & 27.3 & 18.2 & 9.1 & 13.6 & 6.8 \\
\hline
\end{tabular}

bacterium's ability to resist inhibitory sera factors allows it to escape the actions of the complement system and phagocytosis. During the process of infection, the presence of a virulence factor (encoded by the iss gene) associated with this ability is more strongly correlated with a bacterium's level of pathogenicity.

The iss gene has been detected with high frequency in APEC. In this study, 41 (93.20\%) strains were found to possess iss+. These data are in agreement with previous studies that have found levels of iss+ ranging from 80 to $100 \%$ (Ewers et al., 2004; Zhao et al., 2005; Someya et al., 2007; Kwon et al., 2008).

$E$. coli epidemiology is complex and involves humans, animals, the environment and the interactions among these components. According to Ikuno et al. (2006), the presence of virulence genes associated with commensal $E$. coli strains may be used as an indicator of potential risks because these bacteria may be reservoirs of virulence genes. In the same study, which was performed with egg-producing layers with clinical signs of colibacillosis, the facility environment, water consumed by layers and egg shelters, the iss gene was found in $50 \%$ of $E$. coli isolates, being $25 \%$ in the organs, $12.5 \%$ in the egg shelters and the remaining in the water consumed by layers and environment.

Furthermore, the participation of identified virulence factor genes in colibacillosis development has been supported by epidemiological studies that have demonstrated a significantly higher frequency of these genes in isolates from sick birds as compared to isolates of faecal samples from healthy birds (McPeake et al., 2005;
Vandekerchove et al., 2005). However, the frequen-cies of some genes have varied significantly among APEC studies.

The astA gene, which encodes a heat-stable enterotoxin (EAST) found in diarrhoeagenic bacteria, was detected in $88.5 \%$ of APEC analysed by Someya et al. (2007), in $20 \%$ of strains analysed by Ewers et al. (2004) and in $17.8 \%$ in strains studied by Won et al. (2009). In this work, $40.1 \%$ of strains were astA+. Similarly, conflicting results have been found regarding the presence of the gene iucD, which encodes aerobactin, which was found in $43.2 \%$ of analysed strains on this study. Someya et al. (2007) detected this gene in $100 \%$ of analysed APEC, Ewers et al. (2004) detected it in $78 \%$, and Won et al. (2009) detected it in $47.5 \%$ of their studied strains.

The gene that encodes a temperature-sensitive haemagglutinin (tsh) was detected in a low percentage of strains in this study (13.6\%) as compared to results obtained by Zhao et al. (2005) and Won et al. (2009), which found this gene in $46.3 \%$ of analysed strains. Some studies have detected an even lower percentage of $t s h+$ strains, such as the study by lkuno et al. (2006), which found that only $10 \%$ of analysed strains were $t s h+$.

The gene that encodes fimbria $\mathrm{P}$ (papC) has been less frequently detected, with $6.8 \%$ of strains testing positive. This percentage was considered low when compared with data obtained by Won et al. (2009), who reported the presence of this gene in $15.0 \%$ of analysed strains, and Ewers et al. (2004), who reported the presence of this gene in $22.7 \%$ of analysed strains. However, one report 
Table 4. Genetic patterns, number of strains with high and intermediate levels of pathogenicity, isolation sites and serogroups.

\begin{tabular}{|c|c|c|c|c|}
\hline Pattern & Genotype & No. of strains & Organ & Serogroup \\
\hline 1 & iss+, astA $\mathrm{A}$, iucD+, irp2+, cvi/cva+, papC+, tsh+ & 2 & Liver/Intestine & $\mathrm{O} 8 / \mathrm{NT}^{\mathrm{a}}$ \\
\hline 2 & iss+, astA+, iucD+, irp2+, cvi/cva+, tsh+ & 1 & Liver & NT \\
\hline 3 & iss + , ast $\mathrm{A}+$, iucD + , irp2+, cvicva+, vat+ & 1 & Liver & NT \\
\hline 4 & iss+, astA+, iucD+, irp2+, vat+, tsh+ & 1 & Intestine & NT \\
\hline 5 & iss + , iucD+, cvi/cva+, tsh+ & 1 & Liver & 0133 \\
\hline 6 & iss + , astA + , iucD + , irp2+, cvi/cva+, papC+ & 1 & Intestine & NT \\
\hline 7 & iss+, iucD+, vat+, tsh+ & 1 & Liver & NT \\
\hline 8 & iss+, irp2+, cvi/cva+, vat+ & 1 & Liver & NT \\
\hline 9 & iss+, ast $\mathrm{A}+$, cvi/cva+, iucD+ & 1 & Intestine & NT \\
\hline 10 & iss + , astA + , irp2+ & 2 & Intestine & O9/NT \\
\hline 11 & iss+, ast $\mathrm{A}+$, iucD+ & 2 & Liver/Intestine & O23/O112 \\
\hline 12 & iss + , astA+ & 5 & Liver & O8/NT \\
\hline 13 & iss+, iucD+ & 8 & Liver/Intestine & O23/O64/O83/140/O142 \\
\hline 14 & iss + , irp2+ & 3 & Liver/Intestine & O75/NT \\
\hline 15 & iss+ & 11 & Liver/Intestine & O8/O15/O83/O133/NT \\
\hline 16 & $\operatorname{ast} \mathrm{A}_{+}$, papC+ & 1 & Intestine & $\mathrm{O} 64$ \\
\hline 17 & $\operatorname{ast} \mathrm{A}_{+}$ & 2 & Intestine & O8/NT \\
\hline
\end{tabular}

${ }^{\mathrm{a}}$ Not typable.

did not find this gene in any analysed strains of layers with clinical signs of colibacillosis (lkuno et al., 2006).

Several studies have sought to determine the serogroups involved in APEC. Dho-Moulin and Fairbrother (1999) associated the identification of serogroups $\mathrm{O} 1, \mathrm{O} 2$ and $\mathrm{O} 78$ with highly pathogenic strains. However, the results from the present study demonstrate that no potentially pathogenic strain belongs to any of these serogroups. Serogroups O8, O9, O15, O23, O64, O75, O83, 0112 and 0140 , representing $81.8 \%$ of the serogrouped strains in this study, have been cited in studies from several different countries (Blanco et al., 1998; Silveira et al., 2002; Jeffrey et al., 2004; Rosario et al., 2004; Vandekerchove et al., 2005; Zhao et al., 2005; Guastalli et al., 2010) as being involved in avian colibacillosis in chickens.

Blanco et al. (1998) stated that in the last several decades, different studies have demonstrated great antigenic diversity among APEC, with three to five serogroups being predominant among studied strains. In this study, serogroups that appeared at higher frequencies were $08(15.89 \%), \mathrm{O} 23(9.08 \%)$ and $\mathrm{O} 83(6.81 \%)$. The highest prevalence was NT strains. According to Silveira et al. (2002), the diversity of serogroups involved with colibacillosis may reflect regional differences associated with the prevalence of different clonal groups of strains.

In Mexico, Rosario et al. (2004), in a work developed (in a commercial chicken incubator) with strains isolated from infertile eggs and yolk sacs of dead embryos, found the following serogroups: $08,09,015,023,083$ and 0112, representing $54.0 \%$ of the total characterised serogroups in our study. In Brazil, a study with day-old commercial layer chicks identified 14 different serogroups from $E$. coli strains isolated from livers (Guastalli et al., 2010). Four of these serogroups, O8, O15, O64 and O75, were also identified in this study. The involvement of these groups in the aforementioned studies suggests their participation in colibacillosis in young birds or at the embryonic development stage.

The great number of APEC strains that could not be serogrouped makes diagnoses based on serotyping difficult (Dho-moulin and Fairbrother, 1999). In this study, 18 strains (40.9\%) were not typable, in accordance with descriptions in the literature that described non-typable percentages of $14.8-60 \%$ (Silveira et al., 2002; Vandekerchove et al., 2004; Monroy et al., 2005; Zhao et al., 2005; Johnson et al., 2008).

Strains that belong to serogroups 0133 and 0142 , found in the present study, had high and intermediate levels of pathogenicity, respectively, causing 100 and $70 \%$ mortality, respectively, in inoculated chicks; however, these serogroups have not been previously reported as being involved in APEC pathogenicity.

These results demonstrate the diversity of serogroups and virulence genes involved in colibacillosis pathogennesis. Strains that present a single virulence gene and serogroups that have not been commonly identified may be fundamental to disease pathogenesis in the studied chicks. Strains with high and intermediate levels of pathogenicity have been found, demonstrating the importance of studies of $E$. coli of avian origin, particularly in regions that practice intensive poultry industry, to evaluate predominant strains and acquire preventive measures to minimise losses due to colibacillosis. 


\section{ACKNOWLEDGEMENTS}

The authors gratefully acknowledge the Fundação de Amparo à Pesquisa do Estado de São Paulo (FAPESP grant no. 2009/02066-3) and the National Council for Scientific and Technological Development (CNPq - grant no. 578023/2008-3) for financial support.

\section{REFERENCES}

Barnes HJ, Vaillancourt J, Gross WB (2003). Colibacillosis. In Y.M. Saif (Ed.). Dieases of poultry. 11th ed. Y.M. Saif, ed. lowa State University Press, lowa City, IA. pp. 631-652.

Blanco J, Blanco M, Alonso MP, Blanco JE, Garabal JI, Gonzalez EA (1992). Serogroups of Escherichia coli strains producing cytotoxic necrotizing factors CNF1 and CNF2. FEMS Microbiol. Lett. 96:155160.

Blanco JE, Blanco M, Mora A, Jansen WH, Garcia V, Vazquez ML, Blanco J (1998). Serotypes of Escherichia coli isolated from septicaemic chickens in Galícia (Northwest Spain). Vet. Microbiol. 61:229-235.

Dho-Moulin M, Fairbrother, JM (1999). Avian pathogenic Escherichia coli (APEC). Vet. Res. 30:299-316.

Dho-Moulin M, Lafont JP (1982). Escherichia coli colonization of the trachea in poultry: Comparison of virulent and avirulent strains in gnotoxenic chickens. Avian Dis. 26:787-797.

Dozois C M, Fairbrother, JM, Harel J, Bosse M (1992). Pap-and pilrelated DNA sequences and other virulence determinants associated with Escherichia coli isolated from septicemic chickens and turkeys. Infect. Immun. 60:2648-2656.

Ewers C, Janben T, Kiebling S, Philip HC, Wieler LH (2004). Molecular epidemiology of avian pathogenic Escherichia coli (APEC) isolated from colisepticemia in poultry. Vet. Microbiol. 104:91-101.

Ewers C, Janben T, Kiebling S, Philip HC, Wieler LH (2005). Rapid detection of virulence associated genes in avian pathogenic Escherichia coli by multiplex polymerase chain reaction. Avian Dis. 49: 269-273.

Franck SM, Bosworth BT, Moon HW (1998). Multiplex PCR for enterotoxigenic, attaching and effacing and Shiga toxin-producing Escherichia coli strains from calves. J. Clin. Microbiol. 36:1795-1797.

Gross WG (1994). Diseases due to Escherichia coli in poultry. In C.L. Gyles (Ed.). Escherichia coli in domestic animals and humans. UK: Cab International. pp. 237-261

Guastalli EAL, Gama NMSQ, Buim MR, Oliveira RA, Ferreira AJF, Leite DS (2010). Índice de patogenicidade, produção de hemolisina e sorogrupo de amostras de Escherichia coli isoladas de aves de postura comercial. Arq. Inst. Biol. 77:153-157.

Guinée PAM, Agterber CM, Jansen WH (1972). Escherichia coli O typing by means of a mechanized microtechnique. Appl. Microbiol. 24:127-131.

Ikuno AA, Guastalli EAL, Buim MR, Gama NMSQ, França SB, Alonso AC, Fujikura LM, Ferreira VCA (2006). Genes de virulência associados em Escherichia coli (APEC) isoladas de poedeiras comerciais, do meio ambiente e de água de dessedentação de granjas de postura de ovos. Arq. Inst. Biol. 68:132-135.

Janßen T, Schwarz C, Preikschat P, Voss M, Philipp HC, Wieler LH (2001). Virulence-associated genes in avian pathogenic Escherichia coli (APEC) isolated from internal organs of poultry having died from colibacillosis. Braz. J. Vet. Res. Anim. Sci. 291:371-378.

Jeffrey JS, Singer RS, O'Connor R, Atwill ER (2004). Prevalence of pathogenic Escherichia coli in the broiler house environment. Avian Dis. 48:189-195.

Johnson LC, Bilgili SF, Hoerr FJ, Mcmurtrey BL, Norton RA (2001). The influence of Escherichia coli strains from different sources and the age of broiler chickens on development of cellulitis. Avian Pathol. 30:475-479.
Johnson TJ, Wannemuehler Y, Doetkott C, Johnson SJ, Rosenberger SC, Nolan LK (2008). Identification of minimal predictors of avian pathogenic Escherichia coli virulence for use as a rapid diagnostic tool. J. Clin. Microbiol. 46:3987-3996.

Kawano M, Yaguchi K, Osawa R (2006). Genotypic analyses of Escherichia coli isolated from chickens with colibacillosis and apparently healthy chickens in Japan. Microb. Immunol. 50:961-966.

Koneman EW, Allen SD, Janda WM, Schreckenberger PC (1997). Color Atlas and Textbook of Diagnostic Microbiology. Lippincott, New York, NY.

Kwon S, Cha S, Choi E, Kim B, Song H, Jang H (2008). Epidemiological prevalence of avian pathogenic Escherichia coli differentiated by multiplex PCR from commercial chickens and hatchery in Korea. J. Bact. Virol. 38:179-188.

Mcpeake SJW, Smyth JA, Ball HJ (2005). Characterisation of avian pathogenic Escherichia coli (APEC) associated with colisepticaemia compared to faecal isolates from healthy birds. Vet. Microbiol. 110:245-253.

Mellata M, Dho-Moulin M, Dozois CM, Curtis IR, Brown PK, Arné P, Brée A, Desautels C, Fairbrother JM (2003). Role of virulence in resistance of avian pathogenic Escherichia coli to serum and pathogenicity. Infect. Immun. 71:536-540.

Menão MC, Ferreira CSA, Castro AGM, Knöbl T, Piantino Ferreira AJ (2002). Sorogrupos de Escherichia coli isoladas de frangos com doença respiratória crônica. Arq. Inst. Biol. 69 (4):15-17.

Monroy MAR, Knöbl T, Bottino JA, Ferreira CSA, Ferreira AJP (2005). Virulence characteristics of Escherichia coli isolates obtained from broiler breeders with salpingitis. Comp. Immunol. Microbiol. Infect. Dis. 28:1-15.

Montgomery RD, Boyle CR, Lenarduzzi TA, Jones LS (1999). Consequences to chicks hatched from Escherichia coli inoculated embryos. Avian Dis. 43:553-563.

Rosario CC, López CC, Téllez IG, Navarro OA, Anderson RC, Eslava CC (2004). Serotyping and virulence genes detection in Escherichia coli isolated from fertile and infertile eggs, dead-in-shell embryos, and chickens with yolk sac infection. Avian Dis. 48:791-802.

Sanger F, Nicklen S, Coulson AR (1977). DNA sequencing with chairterminating inhibitors. Proceeding of the National Academy of Sciences of the United States of América, 74:5463-5467.

Silveira WDS, Ferreira A, Brocchi M, Hollanda LM, Pestana De Castro AF, Yamada, AT, Lancellotti M (2002). Biological characteristics and pathogenicity of avian Escherichia coli strains. Vet. Microbiol. 85: 4753.

Someya A, Otsuki K, Murase T (2007). Characterization of Escherichia coli strains obtained from layer chickens affected with colibacillosis in a commercial egg-producing farm. J. Vet. Med. Sci. 69:1009-1014.

Vandekerchove $\mathrm{D}$, Vandemaele $\mathrm{F}$, Adriaensen $\mathrm{C}$, Zaleska $\mathrm{M}$, Hernalsteens JP, De Baets L, Butaye P, Van Immerseel F, Wattiau P, Laevens H, Mast J, Goddeeris B, Pasmans F (2005). Virulenceassociated in avian Escherichia coli: comparison between isolates from colibacillosis-affeted and clinically healthy layer flocks. Vet. Microbiol. 108:75-87.

Vandekerchove D, De Herdt P, Laevens H, Pasmans F (2004). Colibacillosis in caged layer hens: characteristics of the disease and the aetiological agent. Avian Pathol. 33:117-125.

Won G, Moon B, Oh I, Matsuda K, Chaudhari AA, Hur J, Eo S, Yu I, Lee Y, Lee Y, Kim B, Lee JH (2009). Profiles of virulence-associated of avian pathogenic Escherichia coli isolates from chickens with colibacillosis. Poult. Sci. 46:260-266.

Zhao S, Maurer JJ, Hubert S, De Villena JF, Mcdermott PF, Meng J, Ayers S, English L, White DG (2005). Antimicrobial susceptibility and molecular characterization of avian pathogenic Escherichia coli isolates. Vet. Microbiol. 107:215-224. 